\title{
Determinants of Portuguese banks' profitability: an update
}

\section{Determinantes da rentabilidade dos bancos portugueses: uma atualização}

\section{Clara Pires}

Instituto Politécnico de Beja, Portugal, clara.pires@ipbeja.pt

\section{Maria Basílio}

Instituto Politécnico de Beja, Portugal, maria.basilio@ipbeja.pt

\section{Carlos Borralho}

Instituto Politécnico de Beja, Portugal, cborralho@ipbeja.pt

Received: 02.12.2020; Revisions required: 03.05.2021; Accepted: 20.07.2021

\begin{abstract}
In this study, we assess the main determinants of banks' profitability in Portugal over the period 2015-2018. We divide the factors that can influence bank profitability into several groups: management quality, credit quality, capital adequacy, liquidity (internal bank factors), and GDP growth (an external factor). The panel dataset is composed of annual report data for the 18 major banks operating in Portugal, representing about $98 \%$ of the Portuguese banking product. Profitability has been a persistent challenge for banks since the global financial crisis. Moreover, the Portuguese banking system had been facing several structural problems, which makes this topic particularly relevant. The profitability proxy used is the return on equity (ROE). The empirical strategy followed was pooled OLS. Variables relevant for explaining Portuguese banks' profitability are capital adequacy, liquidity and credit risk. As expected, the results show that capital adequacy (TIER 1) and credit quality (CVCT) have a negative and significant impact on banks' profitability, whereas liquidity (RAL) has a positive impact.
\end{abstract}

Keywords: Banks, profitability, pooled OLS.

\section{Resumo}

Este estudo avalia os principais determinantes da rendibilidade dos bancos, em Portugal, no período 2015-2018. Dividimos os fatores que podem influenciar a rentabilidade dos bancos em dois grupos, nomeadamente, qualidade da gestão, qualidade do crédito, adequação do capital, liquidez (fatores internos do banco), bem como crescimento do PIB (fator externo). O painel de dados é composto por +relatórios de 18 bancos a operar em Portugal, o que representa cerca de $98 \%$ do produto bancário português. A rentabilidade bancária tem sido um desafio persistente desde a crise financeira global. Acresce que o sistema bancário português tem enfrentado diversos problemas estruturais, o que torna este tema particularmente relevante. A medida de rentabilidade aqui explorada é a rendibilidade dos capitais próprios. A estratégia empírica seguida baseou-se no MMQ com dados agrupados. As variáveis relevantes são a adequação do capital, a liquidez e o risco de crédito. Como esperado, os resultados mostram que a adequação de capital (TIER 1) e a qualidade de crédito (CVCT) têm um impacto negativo e significativo na rentabilidade dos bancos, enquanto a liquidez (RAL) tem um impacto positivo.

Palavras-chave: Bancos, rentabilidade, MMQ com dados agrupados.

\section{Introduction}

The Portuguese banking system is fragile and has recently been plagued by the collapse of some banks, for example, BPN, BANIF and BES. Therefore, the study of bank profitability is a topic that remains current and relevant, given the specificity of the Portuguese banking system, where government intervention has been frequent.

The growth of the banking system increases the role that banks play in each country's economic performance (Ahmad et al., 2019; Arvis et al., 2014; Haupt et al., 2016). The profitability of this sector occupies a prominent place in the concerns of depositors, investors, analysts, managers, regulators and governmental institutions. In fact, a decrease in the level of confidence may result in an unexpected run on deposits, causing a banking crisis with increasingly widespread effects. Diamond and Rajan (2005) show that bank failures can be contagious. A well-functioning and well-developed banking system plays a crucial role in the growth of an economy.

In the literature, multiple elements are highlighted. Levine (1996) analyse the predominant role of capital ratios in prudential regulation, which influence banks' profitability.
Demirguc-Kunt et al. (2012) contribute to a better understanding of the dynamic relationships among economic development, financial institutions, and securities markets. Athanasoglou et al. (2006) confirm the fundamental role that banks have in financing economic activity and their contribution to the financial system's stability. A banking sector showing high levels of profitability and exhibiting good financial health contributes significantly to the stability of the financial system.

For several years European Banks presented high earnings volatility. However, profitability declined in 2008 and subsequently remained at very low levels due to the economic crisis (Carvalho \& Ribeiro, 2016). Despite the increasingly demanding rules in terms of banking supervision that appeared with the third Basel Accord in 2010, the banks' financial situation has not improved. Several banks received substantial amounts of money to correct their financial situation.

In Portugal, BPN was the first bank to be nationalised in November 2008. Another bank in crisis was BPP, but it was not rescued by the Portuguese Government, which led to its bankruptcy in 2010. Many other Portuguese banks suffered huge losses in their profits, and some of them had to be assisted 
by the Government (CGD, BCP, BPI and BANIF). In complement to the Government support, all private banks that were intervened with had to reinforce their capital with private funds. The only exception that did not require the assistance of the Portuguese Government was BES. But in order to increase its capital to comply with TIER 1 requirement, BES leaned on private investors (Garcia \& Guerreiro, 2016).

In Portugal, the profitability of the sector was strongly penalised by the financial and sovereign debt crisis. Banks started to have negative results compared to the high profits they usually had in the pre-crisis situation. The return on assets (ROA) and return on equity (ROE) have oscillated considerably. However, some signs of recovery in the performance of the banking system appeared from 2015 onwards. But, comparing Portugal with the majority of the Euro Area countries, the profitability of the Portuguese banking sector remains at low levels and below the cost of capital (Associação Portuguesa de Bancos, 2020) The banks' growth has not been robust, and the structural problems remain uncontrolled. See, for instance, Novo Banco (formerly $\mathrm{BES})$, which is renegotiating government assistance.

In addition, the sector faces significant challenges that affect its profitability and the ability to attract investors. According to the Associação Portuguesa de Bancos (2020), the following stand out: costs from regulation and supervision, costs from the digital transformation, a low-interest rate scenario, delays in judicial credit recovery and insolvency proceedings and competitive pressure from new operators. Moreover, the Portuguese banking system is subject to a set of constraints that are not placed on its European peers, namely regarding the application of interest rates: the imposition of maximum interest rates on consumer credit, prohibition on the application of negative interest rates on deposits and an obligation to apply negative rates on home loans. Furthermore, there is a prohibition on charging commissions on ATM operations, and banks must contribute to the National Resolution Fund (in addition to contributions to the Single Resolution Fund established in the E.U.).

In addition, the application of the Basel capital agreements is still a concern for Portuguese banks. The Basel agreements seek to mitigate risk in the banking system. Such agreements are intended to ensure the principle of the continuity of banking institutions, not the shareholder's profitability. Regarding the Portuguese reality, the rules established by the third Basel Agreement have been subject to a gradual transposition. The Portuguese supervisory activity is guided by the same internationally practised principles.

All in all, the Portuguese banking sector is facing challenging times. Although some signs of recovery appeared after the last financial crisis, Portuguese banks still have to deal with some regulatory country specificities and are in a worse position, in profitability terms, compared with their European peers.

Future prospects are not bright for the Portuguese banking sector. As a consequence of the pandemic crisis, several special lines of credit for companies and a moratorium regime were implemented by the Government, allowing postponements in capital and interest payments. With these measures reaching an end, a potential increase in the default risk and a severe impact on the banks' conditions are expected. Therefore, new insights about the factors that drive banks' profitability are valuable and may be relevant for the definition of strategies that allow better management of these factors, particularly those that affect profitability negatively.

To the best of our knowledge, recent empirical research explaining the profitability of Portuguese banks, based on their particular characteristics, is very scarce. Only Tembe (2011) and Garcia and Guerreiro (2016) have attempted to explore ROE determinants but using panel data from 1998-2009 and 20022011, respectively.

Typically, researchers distinguish internal vs external factors, considering their controllability (Căpraru \& Ihnatov, 2014; Ebenezer et al., 2017; Hammami et al., 2018; Petria et al., 2015). Some common internal factors affecting profitability are bank size, credit risk, liquidity risk, management efficiency, capital adequacy and business mix. Factors related to the industry and the macroeconomic environments are external factors and may include the banking system concentration, inflation and economic growth.

The main goal of this paper is to study the determinants of Portuguese banks' profitability, using several internal factors and GDP growth as a control variable. To achieve this goal, a pooled OLS model was adopted. The analysis is based on balanced panel data over the period 2015 to 2018 for 18 commercial banks. These 18 banks represent about $98 \%$ of the national banking product. The panel dataset comprises annual data from banks' reports on management quality, credit quality, capital adequacy and profitability.

This paper is structured as follows. Section 2 briefly presents the recent empirical literature about banks' profitability, detailing those about Portugal. Section 3 explains the research methodology and the econometric approach and presents the data. Section 4 presents and discusses the results. Finally, Section 5 provides the main conclusions.

\section{Literature review}

The determinants of banks' profitability have been extensively studied in recent years. Most of the papers focus on the individual banks and on the developed markets. However, recently more attention has been given to some emerging regions and countries.

Based on prior literature, bank profitability determinants can be grouped into two clusters. The first group of research examines factors that drive the level of bank profitability using crosscountry data, for example, Al-Harbi (2019) studied 52 developing and underdeveloped countries from the Organization of Islamic Cooperation states; Athanasoglou et al. (2006) explored the South Eastern European banking sector 
(namely, Albania, Bosnia-Herzegovina, Bulgaria, Croatia, FYROM, Romania and Serbia and Montenegro); Căpraru and Ihnatov (2014) approached five selected European countries from Central and Eastern Europe; Martinho et al. (2017), Pasiouras and Kosmidou (2007) and Petria et al. (2015) analysed the European banking sector.

The second cluster is based on data from a particular country. For example, various studies have concentrated on the U.K. (Kosmidou et al., 2005), Greece (Kosmidou et al., 2007), France (Rouissi et al., 2009), Spain (Trujillo-Ponce, 2013), the USA (Zhang and Dong, 2011), Tunisia (Hammami et al., 2018; Rekik \& Kalai, 2018), Nigeria (Akinkunmi, 2017; Ebenezer et al., 2017), India (Almaqtari et al., 2018; Boateng, 2018; Boora \& Kavita, 2018; Makkar \& Hardeep, 2018), the United Arab Emirates (Mehta \& Bhavani, 2017), Albania (Hallunovi, 2017), Kosovo (Nuhiu et al. 2017), Bangladesh (Islam \& Rezwanul, 2017) and China (Tan, 2016).

Usually, the profitability proxies used are the return on equity (ROE), computed as the net profit ratio to equity, and the return on assets (ROA), as the ratio of the net profit to the total assets of the bank. While ROE expresses the net return of the capital invested by the shareholders, the ROA shows the net relative profit generated by the banks' total assets and is considered a measure of management efficiency (Petria et al., 2015). A drawback of ROA is the existence of off-balance-sheet assets, which represent an important source of profit for banks, but are not considered in this measure. Thus, Goddard et al. (2004) argue that the use of ROE is more appropriate because it measures banks' profitability more perfectly. However, it is possible to find studies that use both measures of profitability, ROA and ROE (Athanasoglou et al., 2006; Garcia \& Guerreiro, 2016; Hammami et al., 2018; Nuhiu et al., 2017; Petria et al., 2015; Rekik \& Kalai, 2018; Tembe, 2011; Zhang \& Dong, 2011).

On the other hand, the literature splits the factors that influence banks' profitability into two large groups: bankspecific (internal) factors and macroeconomic (external) factors. The internal factors that usually influence profitability are bank size, financial structure, credit quality, liquidity risk, business mix, income-expenditure structure and capital adequacy. Macroeconomic factors revealed by the literature are, in essence, GDP growth and inflation rate (Almaqtari et al., 2018; Garcia \& Guerreiro, 2016; Martinho et al., 2017; Petria et al., 2015).

Little research has been conducted for Portugal where commercial banks are a cornerstone of the economy. As far as we know, only Tembe (2011), Garcia and Guerreiro (2016) and Carvalho and Ribeiro (2016) have explored this issue. Tembe (2011) studies the impact of bank-specific factors, industry and macroeconomic factors on bank profitability from the period 1998 to 2009, with a sample of 29 banks. The results show that capital adequacy and bank efficiency positively impact the return on average assets (ROAA). On the other hand, credit risk negatively affects the return on average equity (ROAE). The inflation rate has a negative effect on ROAA, and the real GDP growth rate has a positive effect on ROAE and ROAA.

Also, Garcia and Guerreiro (2016) analyse the profitability of 27 universal banks in Portugal over the period between 2002 and 2011. The research conducts ordinary least squares (OLS) estimations with fixed effects using three measures of profitability: the return on average assets, the return on average equity and the net interest. The results obtained reveal that the cost-income ratio has a negative and highly significant effect on profitability measures; the loan loss impairment over overdue loans presents a negative impact on ROE; and finally, GDP growth has a negative impact in bank's profitability (either for ROE or ROA).

In addition, Carvalho and Ribeiro (2016) analyse the profitability of financial institutions operating in Portugal but using ROA. A sample of 29 banks was used, with data from 2002 to 2012, and the estimated results were obtained through OLS. Results suggest that the variables concentration, capital adequacy, debt ratio and credit and accrued interest proved to be statistically significant in explaining banking profitability.

\section{Data and methodology}

The goal of this research is to explore the determinants of Portuguese banks' profitability. The choice of both dependent and independent variables was based on the literature.

Hence, to study the impact on banks' profitability, the measure of profitability chosen was ROE, computed as the ratio between the bank's net profit and equity. As already noted, ROE has the potential to measure banks' profitability more thoroughly than ROA (Goddard et al., 2004). Also, Petria et al. (2015) argue that ROE expresses the net return of the capital invested by the shareholders, whereas ROA shows the net profit generated by banks' total assets and is more appropriate for evaluating management efficiency and not banks' profitability.

We divided our independent variables into two groups following the related literature: bank-specific characteristics (internal factors) and macroeconomic variables (external factors). In the first group, the following six variables were considered:

- The cost-income ratio (CTIN) is defined as operating expenses (mainly staff costs, general and administrative expenses, depreciation and amortisation) over total gross revenues. It measures a bank's operating costs as a proportion of its total revenues and indicates the efficiency of a bank's management. A negative impact on banks' profitability is expected since a high level of expenses can lead to a reduction in profits (similarly to Tembe, 2011; Trujillo-Ponce, 2013).

- The overdue loans over total loans (CVCT) or nonperforming loans affect banks' profitability negatively. This ratio measures credit risk quality. Typically, an increase in 
the proportion of non-performing loans will decrease banks' profitability (Martiningtiyas \& Nitinegeri, 2020).

- Tier 1 (TIER 1) is defined as basic own funds or highest quality own funds over risk-weighted assets. This ratio measures capital adequacy and financial strength. But there is no consensus in the literature about the expected sign of this variable. In general, banks with higher capital ratios are considered safer and more able to cope with crises. Furthermore, higher levels of equity decrease the cost of capital, with a positive impact on profitability. Some authors expect a positive relationship between capitalisation and profitability (Al-Harbi, 2019; Athanasoglou et al., 2006; Pasiouras \& Kosmidou, 2007). However, the conventional risk-return hypothesis points in the opposite direction and implies a negative relationship. According to Goddard et al. (2004), excessively high levels of capital may be a sign that a bank is operating overcautiously and ignoring potentially profitable investment opportunities. In this empirical research, we follow the latter argument.

- Bank Size (LOGAT), computed as the logarithm of the total bank assets. This proxy is extensively used in the prior literature, and its impact on banks' profitability is unpredictable. Usually, when the average size of the banks in the sample is small, a positive correlation between bank size and profitability is expected (Athanasoglou et al., 2006; Trujillo-Ponce, 2013).

- The loan loss impairment over overdue loans (ICV) is a proxy for credit risk. The higher this ratio is, the lower the banks' credit quality will be, which then leads to lower profitability. We expect a negative impact of this variable on banks' profitability (in the same vein as Garcia \& Guerreiro, 2016, or Tan, 2016).

- Liquidity ratio (RAL) is defined as the percentage of liquid assets to total assets. Usually, banks that are more liquid may provide opportunities for higher returns. The lack of adequate levels of liquidity is considered one major cause of banks' failure. We expect that the liquidity ratio shows a positive impact on banks' profitability, in line with Bourke (1989), who reported a positive association between liquidity ratios and profitability. However, Goddard et al. (2004) argue that banks with a high portion of liquid assets are less exposed to risk; therefore, shareholders should be willing to accept a lower return on equity.

Regarding external factors, we used the macroeconomic variable GDP Growth (GDP) as a control variable. In fact, GDP growth is the macroeconomic factor most widely used to assess the impacts of the economic cycle on banks' profitability. The impacts of this variable are mixed. According to the literature, some authors (Hammami et al., 2018; Kosmidou et al., 2005; Tembe, 2011; Zhang and Dong, 2011) reported a positive effect. However, Garcia and Guerreiro (2016) signalised a negative effect. Furthermore, in some studies, this variable returned insignificant (see, for instance, Al-Harbi, 2019). We expect a positive effect from this variable because banks will have no difficulty collecting loans and financing the economic activity with the real growth of the economy.

The time span of this research is only four years, and we consider the 18 major banks operating in Portugal. Because our sample is considered small, this prevents us from using a larger set of macroeconomic variables, such as the inflation rate, an important determinant of profitability for several authors (Căpraru \& Ihnatov, 2014; Tembe, 2011).

We use panel data of 18 banks for the years between 2015 and 2018. The panel dataset is composed of annual data retrieved from the banks' annual reports on management efficiency, credit quality, capital adequacy and profitability. The sample of 18 banks includes BPI, CATV, BCP, CGD, SICAM, CAL, STD, MTP, $\mathrm{NB}, \mathrm{BIC}, \mathrm{BIG}, \mathrm{CTT}, \mathrm{BAI}, \mathrm{FNT}, \mathrm{CTL}, \mathrm{BKT}, \mathrm{D} . \mathrm{B}$. and BEST and it represents about $98 \%$ of the Portuguese banking product. The variable GDP growth was obtained online via INE databases (Statistics of Portugal).

Table 1 summarises the independent variables used and the expected effect on ROE.

Table 1 - Independent variables definition

\begin{tabular}{|c|l|c|}
\hline Variable & \multicolumn{1}{|c|}{ Definition } & Expected effect \\
\hline CTIN & Cost-income ratio - operational expenses divided by total gross revenues & - \\
\hline CVCT & Overdue loans over total loans & - \\
\hline TIER 1 & Basic own funds or highest quality own funds, over risk-weighted assets & - \\
\hline LOGAT: Bank Size & The logarithm of the total bank assets & + \\
\hline ICV & Measured by loan loss impairment divided by overdue loans & - \\
\hline RAL: Liquidity ratio & The percentage of liquid assets to total assets & + \\
\hline GDP & GDP Growth & + \\
\hline
\end{tabular}

Source: Own elaboration.

As control variables and following Wooldridge (2016), we try to use year dummies to capture any effects associated with time. However, due to collinearity problems with the variable GDP, year dummies were dropped.
Regarding the econometric methodology, the researchers' preferences seem to rest on panel data analysis. Several advantages are pointed out, namely, the ability to control for variables not observed or measured (it accounts for individual heterogeneity), more accurate inference of model parameters 
and more accurate predictions. Panel data usually contain more degrees of freedom and more sample variability than crosssectional or time-series data, thus improving the efficiency of econometric estimates (Marques, 2000).

Our panel is balanced because the information is available for all the 18 banks in the four years. The model is the following:

$$
Y_{i, t}=\beta_{0}+\sum_{k=1}^{7} \beta_{k} X_{k i, t}+\varepsilon_{i, t}
$$

where:

$Y_{i, t}=\operatorname{ROE}$ from bank $i(i=1, \ldots 18)$ and year $t(t=2015$, ...2018)

$\beta_{0}=$ constant

$\beta_{k}=$ coefficients to be estimated by the model

$\mathrm{X}=$ vector of the explanatory variables

$\varepsilon_{i, t}=$ random error
Three models were tested: the pooled OLS (POLS), the fixed effects model (FE) and the random-effects model (RE). In order to choose the most appropriate model, the usual tests were performed. The F test for Fixed Effects, the Breusch-Pagan Lagrangian multiplier test and the Hausman test.

The POLS model was chosen because it achieves the best results, given the small dimension of our sample. In addition, cluster-robust standard errors were used to control for heteroscedasticity and autocorrelation. We follow this option because each bank is considered a cluster, and naturally, the observations of one year will be related to the observations of the previous year of that same bank, allowing for intragroup correlation (a more reasonable assumption) and relaxing the usual requirement that the observations are independent. Observations are independent across banks (clusters) but not necessarily within groups.

The regressions were performed using the statistical software STATA 14. Table 2 presents the summary statistics of all the variables.

Table 2 - Summary statistics

\begin{tabular}{|c|c|c|c|c|c|}
\hline Variable & N & Mean & Std. Dev. & Min & Max \\
\hline ROE (\%) & 72 & 3.881 & 12.482 & -37.0 & 27.7 \\
\hline ICV (\%) & 72 & 84.517 & 55.303 & 20.0 & 453.0 \\
\hline CVCT (\%) & 72 & 5.042 & 4.396 & 0.0 & 18.7 \\
\hline RAL (\%) & 72 & 1.348 & 0.837 & 0.5 & 4.7 \\
\hline CTIN (\%) & 72 & 53.971 & 17.184 & 4.4 & 100.6 \\
\hline TIER 1 (\%) & 72 & 18.548 & 11.808 & 8.8 & 82.3 \\
\hline LOGAT (In) & 72 & 3.722 & 0.878 & 1.5 & 4.9 \\
\hline GDP (\%) & 72 & 2.100 & 0.445 & 1.6 & 2.8 \\
\hline
\end{tabular}

Source: Own elaboration based on STATA 14 results.

Table 2 reports the descriptive statistics of all the variables included in the study, summarising some of the properties of the banks' dataset. For each variable, the mean, standard deviation, minimum and maximum value is presented. On average, the selected banks have a return on equity ROE of $3.9 \%$, with a standard deviation of $12.5 \%$, showing large profitability heterogeneity among the banks in our sample. It should be noted that several banks even exhibited negative returns in all years of analysis, namely, NB (Novo Banco) and CTT (Banco CTT), being the minimum $-37 \%$.

By contrast and as expected, variables such as GDP growth and bank size show a low standard deviation, revealing stability in the 2015-2018 period.
Because collinearity may cause problems, turning the regression coefficients unreliable, the multicollinearity diagnostic was performed using the VIF (variance inflation factor) measure available in STATA (VIF is an indicator of how much of the inflation of the standard error could be caused by collinearity). As a rule of thumb, values above 10 should be a cause for concern and must be corrected. The mean VIF obtained was 1.56, the highest value being the LOGAT (2.29), which are satisfying results. In addition, Table 3 presents the correlation matrix.

Table 3 - Pearson's Correlation Matrix for the independent variables

\begin{tabular}{|c|c|c|c|c|c|c|c|}
\hline & ICV & CVCT & RAL & CTIN & TIER1 & LOGAT & GDP \\
\hline ICV & 1 & & & & & & \\
\hline CVCT & -0.1239 & 1 & & & & & \\
\hline RAL & 0.0769 & 0.1978 & 1 & & & & \\
\hline CTIN & 0.2156 & $0.3577^{*}$ & -0.1266 & 1 & & & \\
\hline TIER 1 & 0.1304 & $-0.4082^{*}$ & -0.0407 & $-0.2936^{*}$ & 1 & & \\
\hline LOGAT & 0.0573 & $0.2478^{*}$ & $-0.3455^{*}$ & $0.4162^{*}$ & $-0.6094^{*}$ & 1 & \\
\hline GDP & -0.0178 & 0.0513 & 0.0306 & -0.0643 & -0.0671 & 0.052 & 1 \\
\hline
\end{tabular}


No collinearity problems were identified. Only the correlation between LOGAT and TIER1 is slightly above $60 \%$. This matrix is used just to give a brief overview of the direction and strengths of the correlations.

\section{Results and Discussion}

The results presented in Table 4 show that the POLS model is considered appropriate, given the results of the $\mathrm{F}$ statistic, which is significant at $1 \%$ level. The R-squared is $51 \%$, meaning that $51 \%$ of the variance of ROE is explained by the set of independent variables used.

As a robustness check, a misspecification test was run (a Ramsey test), which demonstrated the meaningfulness of the covariates chosen and a correct assumption for the specified function ( $p$-value of the yhat squared $=0.783$ ).

Table 4 - Regression results

\begin{tabular}{|c|c|c|c|c|}
\hline $\mathbf{y}=$ ROE & Coef. $(\boldsymbol{\beta})$ & $\begin{array}{c}\text { Cluster robust } \\
\text { Standard Error }\end{array}$ & $\mathbf{t}$ & $\mathbf{p}$-value \\
\hline ICV & 0.009 & 0.013 & 0.74 & 0.468 \\
\hline CVCT & $-1.973^{* * *}$ & 0.425 & -4.64 & 0.000 \\
\hline RAL & $4.607^{* *}$ & 1.919 & 2.40 & 0.028 \\
\hline CTIN & -0.100 & 0.090 & -1.11 & 0.283 \\
\hline TIER 1 & $-0.437^{* *}$ & 0.182 & -2.40 & 0.028 \\
\hline LOGAT & 2.513 & 2.467 & 1.02 & 0.323 \\
\hline GDP & -0.134 & 2.629 & -0.05 & 0.960 \\
\hline Constant & 11.232 & 14.844 & 0.76 & 0.460 \\
\hline Number of observations & \multicolumn{5}{|c|}{$51.08 \%$} \\
\hline $\mathrm{R}^{\wedge} 2$ & \multicolumn{5}{|l}{} \\
\hline
\end{tabular}

Source: Own elaboration based on STATA 14 results.

Of particular significance appears to be CVCT, presenting the expected sign and statistically significant at $1 \%$ level. This variable (credit quality) shows that banks with a higher level of non-performing loans will have lower profitability. A higher default also involves the establishment of greater provisions (impairment), which implies a reduction of the bank net income. This result is similar to that found by Tembe (2011), Garcia and Guerreiro (2016), and Islam and Rezwanul (2017), and against the results of Trujillo-Ponce (2013), Cãpraru and Ihnatov (2014), and Hammami et al. (2018).

The variable TIER 1 (Capital Adequacy) shows the expected sign, and it is statistically significant at $5 \%$ level. This result corroborates the idea that the higher the ratio, the lower the need for external funding, inducing lower profitability. Usually, it shows that the bank could absorb losses and handle risk exposure with shareholders. The implication is that as capital adequacy increases, ROE also decreases. Higher capitalisation has a negative impact on banks' profitability. This result is in line with Tembe (2011), Zhang and Dong (2011), Carvalho and Ribeiro (2016) and contrary to Hallunovi (2017), Hammami et al. (2018).

Also, RAL is statistically significant at $5 \%$ level and exhibits the expected effect. RAL measures the relationship between liquid assets and total assets, exhibiting a positive but strong impact on banks' profitability. The existence of liquidity increases the likelihood of presenting better net results. This conclusion is that of several authors, such as Bourke (1989), Rouissi et al. (2009), Ebenezer et al. (2017) and Makkar and Hardeep (2018). Finally, the analysis of the results shows that the variables CTIN, LOGAT, ICV and GDP are not statistically relevant. The variable CTIN, which measures operational efficiency, shows a negative although not statistically relevant impact on banks' profitability. The bank size and ICV (another measure of credit quality) have a positive but not statistically significant impact on banks' profitability. Also, Al-Harbi (2019) found similar results for these variables. Concerning GDP growth, this variable presents a negative sign, but it is not statistically relevant. In the empirical literature, the results are mixed. Some authors, for example, Kosmidou et al. (2005), Zhang and Dong (2011), Tembe (2011) and Hammami et al. (2018) reported a positive effect, while others, namely Garcia and Guerreiro (2016), reported a negative effect but with low statistical significance. Similarly to our results, Al-Harbi (2019) found this variable insignificant.

\section{Conclusions}

The main goal of this paper was to identify the key factors that influence Portuguese banks' profitability, based on internal and external factors from the perspective of bank management. This research is included in the cluster of studies focusing on banks' profitability within individual countries.

Among the most important internal factors, management quality, credit quality, capital adequacy and liquidity were considered. In addition, GDP growth was used as an important external factor to control for general economic conditions.

For this purpose, we consider a panel sample of 18 banks operating in Portugal for the period 2015 to 2018 and use pooled OLS (POLS) as the econometric approach. The most important determinant of Portuguese banks' profitability is $\mathrm{CVCT}$, showing the expected negative sign. Also, TIER1 presents a negative and significant impact on banks' profitability. By contrast, RAL shows a positive impact on profitability. Finally, 
the analysis of the results shows that the variables CTIN, LOGAT, ICV and GDP are not statistically relevant in explaining profitability.

Comparing our results with those of Tembe (2011) and Garcia and Guerreiro (2016), in what concerns ROE, the importance of CTIN as an explanatory variable of profitability was not confirmed with this research. But similar results were obtained considering size, so this variable is not important for explaining profitability. However, we find different results concerning GDP growth: Tembe (2011) recorded a positive and strong effect on profitability, whereas Garcia and Guerreiro (2016) reported a negative effect but with low significance; and here, GDP growth seems not to influence banks' profitability. This result may be a consequence of the short time span of the analysis.

All research has limitations. The first and foremost is the necessity to expand the analysis to include more years and to use more robust econometric approaches. Secondly, the variables that were chosen may also impact the results and, related to the first limitation, considering more years would allow the inclusion of other potential relevant macroeconomic and industry factors.

Profitability is a fundamental prerequisite for a healthy banking sector. This topic is relevant for bank management and supervision/regulation entities as well as the general community. It is particularly relevant for Portugal, after the recent crisis and where there are still signs of severe structural problems. Further, the difficulties to cope with stricter legal requirements, leads to lower levels of profitability compared with other Euro area countries (Associação Portuguesa de Bancos, 2020).

In addition, the topic of profitability should be explored in the context of supervision transformations, namely, greater requirements of capital adequacy. It is a fact that, regardless of the tighter rules of supervision, namely capital adequacy and credit quality, that are increasingly demanding, the financial problems of Portuguese banks remain uncontrolled. Since the global financial crisis of 2008, profitability has been at stake for banks in several advanced economies. Some monetary policy accommodation has provided some support for bank profits dealing with very low interest rates and compressed banks' net interest margins. However, as a result of the coronavirus (COVID-19) outbreak, a persistent period of low interest rates is likely to put further pressure on bank profitability over the medium term. This new crisis may induce banks to recoup lost profits by taking excessive risks. As such, new vulnerabilities may appear in the banking system (IMF, 2020).

Like other studies carried out for the Portuguese banking sector, namely Tembe (2011) or Garcia and Guerreiro (2016), it is evident that banks must see their results reduced in substitution for greater security and credibility, but without jeopardising their survival and growth.
In this framework, the supervisory entity has an enhanced important role, despite all efforts carried out with increasingly demanding ratios imposed by the third Basel Accord, namely of liquidity, credit quality and capital adequacy. So far, it seems that the rules imposed by the different Basel Accords have not been sufficient to prevent the fragilities of the Portuguese bank system. The resilience of the financial system is a cornerstone in which a country's economy should be supported to face future challenges better.

\section{References}

Ahmad, N., Naveed, A., Ahmad, S., \& Butt, I. (2019). Banking sector performance, profitability, and efficiency: A citation-based systematic literature review. Journal of Economic Surveys, 34(1), 185-218. https://doi.org/10.1111/joes.12346

Akinkunmi, M. A. (2017). Determinants of banks' profitability in Nigeria: Does relative market power matter? Journal of Finance and Bank Management, 5(1), 42-53. https://doi.org/10.15640/jfbm.v5n1a4

Al-Harbi, A. (2019). The determinants of conventional banks profitability in developing and underdeveloped OIC countries. Journal of Economics, Finance and Administrative Science, 24(47), 5-28. https://doi.org/10.1108/JEFAS-05-2018-0043

Almaqtari, F. A., Al-Homaidi, E. A., Tabash, M. I., \& Farhan, N. H. (2018). The determinants of profitability of Indian commercial banks: A panel data approach. International Journal of Finance \& Economics, 24(1) 168-185. https://doi.org/10.1002/ijfe.1655

Arvis, J.-F., Saslavsky, D., Ojala, L., Shepherd, B., Busch, C., \& Raj, A. (2014). The Logistics Performance Index and Its Indicators. The International Bank for Reconstruction and Development/The World Bank.

Associação Portuguesa de Bancos. (10 May 2020). Sector Bancário Português. Retrieved from https://www.apb.pt/content/files/2020.01.30__Sector_bancrio_portugus_v5_(002).pdf

Athanasoglou, P. P., Delis, M. D., \& Staikouras, C. K. (2006). Determinants of bank profitability in the South Eastern European region. MPRA Paper 10274. Retrieved from https://mpra.ub.unimuenchen.de/10274/

Boateng, K. (2018). Determinants of Bank Profitability: A Comparative Study of Indian and Ghanaian Banks. Journal of Emerging Technologies and Innovative Research, 5(5), 643-654.

Boora, K. K., \& Kavita. (2018). The impact of Basel III Norms on profitability: An empirical study of Indian public sector banks. IUP Journal of Financial Risk Management, 15, 1-16.

Bourke, P. (1989). Concentration and other determinants of bank profitability in Europe, North America, and Australia. Journal of Banking and Finance, 13(1), 65-79.

Căpraru, B., \& Ihnatov, I. (2014). Banks' profitability in selected Central and Eastern European Countries. Procedia Economics and Finance, 16, 587-591. https://doi.org/10.1016/S2212-5671(14)00844-2

Carvalho, J. F., \& Ribeiro, A. (2016). Fatores Explicativos da Rendibilidade do Setor Bancário: Evidência empírica em Portugal. Estudos do ISCA, Série IV(13), 1-11.

Claessens, Stijn, Coleman, N., \& Donnelly, M. (2017). "Low-for-long" interest rates and banks' interest margins and profitability: Crosscountry evidence. International Finance Discussion Papers, 1-42. https://doi.org/10.17016/IFDP.2017.1197

Demirguc-Kunt, A., Feyen, E., \& Levine, R. (2012). The evolving importance of banks and securities markets. National Bureau of Economic Research - Nber Working Paper Series. http://www.nber.org/papers/w18004

Diamond, D. W., \& Rajan, R. G. (2005). Liquidity shortages and banking crises. The Journal of Finance, LX(2), 615-647.

Ebenezer, O. O., Omar, W. A., \& Kamil, S. (2017). Bank specific and macroeconomic determinants of commercial bank profitability: 
Empirical evidence from Nigeria. Journal of Finance \& Banking Studies, 6(1), 25-38. https://doi.org/10.20525/ijfbs.v6i1.627

Garcia, M. T., \& Guerreiro, J. P. (2016). Internal and external determinants of banks' profitability: The Portuguese case. Journal of Economic Studies, 43, 90-107. https://doi.org/10.1108/JES-09-20140166

Gischer, H., \& Jüttner, D. J. (2011). Profitability and Competition in Banking Markets: An Aggregative Cross Country Approach. Volkswagen Research Foundation, 1-19. Retrieved from https://www.researchgate.net/publication/267771722_Profitability_a nd_Competition_in_Banking_Markets_An_Aggregative_Cross_Countr Y_Approach

Goddard, J., Molyneux, P., \& Wilson, J. O. (2004). The profitability of European banks: A cross-sectional and dynamic panel analysis. The Manchester School, 72(3), 363-381.

Hallunovi, A. (2017). Determinants of profitability according to groups of banks in Albania. ILIRIA International Review, 7(1), 36-46. https://doi.org/10.21113/iir.v7i1.280

Hammami, S., Lassoued, M., \& Berteji, A. (2018). The Tunisian banks performance. Noble International Journal of Economics and Financial Research, 3(1), 1-19.

Haupt, M., Vadenbo, C., \& Hellweg, S. (2016). Do we have the right performance indicators for the circular economy? Journal of Industrial Ecology, 21(3), 615-627.

IMF. (2020). Global Financial Stability Report. International Monetary Fund.

https://www.imf.org/en/Publications/GFSR/Issues/2020/04/14/global -financial-stability-report-april-2020\#Chapter4

Islam, A., \& Rezwanul, H. (2017). Determinants of bank profitability for the selected private commercial banks in Bangladesh: A panel data analysis. Banks and Bank Systems, 12(3), 179-192.

Jong, A. d., Kabir, R., \& Nguyen, T. T. (2008). Capital structure around the world: The roles of firm- and country-specific determinants. Journal of Banking \& Finance, 32, 1954-1969. https://doi.org/10.1016/j.jbankfin.2007.12.034

Kosmidou, K., Pasiouras, F., \& Tsaklanganos, A. (2007). Domestic and multinational determinants of foreign bank profits: The case of Greek banks operating abroad. Journal of Multinational Financial Management, 17(1), 1-15. https://doi.org 10.1016/j.mulfin.2006.02.002

Kosmidou, K., Tanna, S., \& Pasiouras, F. (2005). Determinants of profitability of domestic U.K. commercial banks: Panel evidence from the period 1995-2002. 37th Annual Conference of the Money, (pp. 128). Rethymno. Retrived from http://wwwm.coventry.ac.uk/bes/cubs/aboutthebusinessschool/Econ omicsfinancea

Levine, R. (1996). Foreign banks, financial development, and economic growth. Journal of Economic Literature, 35, 224-254.

Lopez, J. A., Rose, A. K., \& Spiegel, M. M. (2020). Why have negative nominal interest rates had such a small effect on bank performance? Cross country evidence. European Economic Review, 124, 1-17. https://doi.org/10.1016/j.euroecorev.2020.103402

Makkar, A., \& Hardeep. (2018). Key factors influencing profitability of Indian commercial banks. International Journal of Academic Research and Development, 3(1), 373-378.

Marques, L. D. (2000). Modelos Dinâmicos com Dados em Painel: revisão de literatura. Faculdade de Economia da Universidade do Porto. Retrieved from http://wps.fep.up.pt/wplist.php

Martinho, R., Oliveira, J., \& Oliveira, V. (2017). Bank profitability and macroeconomic factors. Financial Stability Papers. Retrieved from www.bportugal.pt

Martiningtiyas, C. R., \& Nitinegeri, D. T. (2020). The effect of nonperforming loans on profitability in banking sector in Indonesia. Advances in Economics, Business and Management Research, 151, 6467.
Mehta, A., \& Bhavani, G. (2017). What determines banks' profitability? Evidence from emerging markets - the case of the UAE banking sector. Accounting and Finance Research, 6(1), 77-88.

Nuhiu, A., Hoti, A., \& Bektashi, M. (2017). Determinants of commercial banks profitability through analysis of financial performance indicators: Evidence from Kosovo. Business: Theory and Practice, 18, 160-170. https://doi.org/10.3846/btp.2017.017

Pasiouras, F., \& Kosmidou, K. (2007). Factors influencing the profitability of domestic and foreign commercial banks in the European Union. Research in International Business and Finance, 21(2), 222-237. https://doi.org/10.1016/j.ribaf.2006.03.007

Petria, N., Capraru, B., \& Ihnatov, I. (2015). Determinants of banks' profitability: Evidence from E.U. 27 banking systems. Procedia Economics and Finance, 20, 518-524.

Rekik, M., \& Kalai, M. (2018). Determinants of banks' profitability and efficiency: Empirical evidence from a sample of banking systems. Journal of Banking and Financial Economics, 1(9), 5-23. https://doi.org/10.7172/2353-6845.jbfe.2018.1.1

Rouissi, R. B., Sassi, S., \& Bouzgarrou, H. (2009). L'analyse des déterminants de la rentabilité des banques françaises (Determinants of French banks profitability: Comparison between domestic banks and foreign banks). SSRN, 1-31. http://dx.doi.org/10.2139/ssrn.2891005

Tan, Y. (2016). The impacts of risk and competition on bank profitability in China. Journal of International Financial Markets, Institutions \& Money, 85110. https://doi.org/dx.doi.org/10.1016/j.intfin.2015.09.003

Tembe, V. I. (2011). Determinantes da rendibilidade no sector bancário: evidência empírica de Portugal [Master's thesis, Universidade Técnica de Lisboa]. https://www.repository.utl.pt/handle/10400.5/4628

Trujillo-Ponce, A. (2013). What determines the profitability of banks? Evidence from Spain. Accounting and Finance, 53, 561-586. https://doi.org/10.1111/j.1467-629X.2011.00466.x

Wooldridge, J. M. (2016). Introductory econometrics: a modern approach (6th ed.). Cengage Learning.

Yahya, A. T., Akhtar, A., \& Tabash, M. I. (2017). The impact of political instability, macroeconomic and bank-specific factors on the profitability of Islamic banks: An empirical evidence. Investment Management and Financial Innovations, 14(4), 30-39.

Zhang, C., \& Dong, L. (2011). Determinants of bank profitability: Evidence from the U.S. banking sector. [Research project, Beedie School of Business, Simon Fraser University]. http://summit.sfu.ca/item/13065 